СД-33.

\title{
РАЗРАБОТКА ЭЛЕКТРОДА, МОДИФИЦИРОВАННОГО ВОССТАНОВЛЕННЫМ ОКСИДОМ ГРАФЕНА, ПОКРЫТЫМ ПОЛИФОЛИЕВОЙ ПЛЕНКОЙ И ЕГО ИСПОЛЬЗОВАНИЕ ДЛЯ ВОЛЬТАМПЕРОМЕТРИЧЕСКОГО ОПРЕДЕЛЕНИЯ И АМПЕРОМЕТРИЧЕСКОГО ДЕТЕКТИРОВАНИЯ АЦИКЛОВИРА И
} ВАЛАЦИКЛОВИРА

Поздняк А.А., Гедмина А.В., Челнокова И.А., Шайдарова Л.Г., Будников Г.К. Химический институт им. А.М. Бутлерова, КФУ, г. Казань, anya_pozdnyak@mail.ru

DOI: 10.26902/ASFE-11_126

В настоящее время все больший интерес вызывает разработка вольтамперометрических способов определения широкого круга органических соединений, в том числе биологически активных на ХМЭ на основе неорганических проводящих полимерных пленок, функционирующих на основе принципов электрокатализа.

Изучено электроокисление ацикловира (АцВ) и валацикловира (ВАцВ) на электроде с пленкой из полифолиевой кислоты (поли-ФК), нанесенной на стеклоуглеродную (СУ)

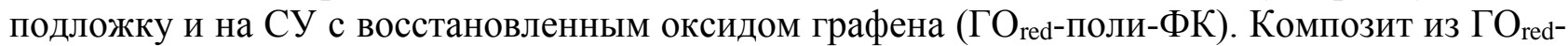
поли-ФК получали в две стадии: сначала капельным методом на поверхность СУ наносили суспензию оксида графена с хитозаном, которую высушивали под ИК-лампой с дальнейшим восстановлением оксида графена до ГО $\mathrm{O}_{\mathrm{red}}$, после в потенциодинамическом режиме проводили электрополимеризацию пленки из фолиевой кислоты. Установлено, что большие значения токов окисления АцВ и ВАцВ и величины электрокаталитических эффектов регистрируются

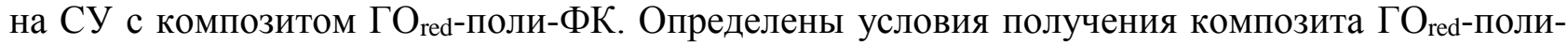
ФК, при которых регистрируются наилучшие электрохимические и электрокаталитические характеристики окисления ацикловира и валацикловира. Так, максимальный электрокаталитический эффект при окислении АцВ и ВАцВ наблюдался при иммобилизации

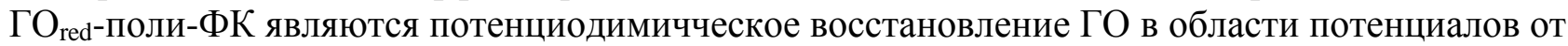
0.60 В до $-1.50 \mathrm{~B}$ в течении 20 циклов и полимеризации фолиевой кислоты в области потенциалов от -1.0 В до 2.0 В в течении 30 циклов из 5 мМ раствора фолиевой кислоты в фосфатном буферном растворе с $\mathrm{pH} 6.86$.

Разработаны способы вольтамперометрического определения ацикловира и валацикловира на электроде поли-ФК-ГОred. Показана возможность использования разработанного высокочувствительного вольтамперометрического способа определения рассматриваемых органических соединений (нижняя граница определяемых содержаний составила $\left.5 \times 10^{-7} \mathrm{M}\right)$ в лекарственных средствах. 